\title{
Metode Spatial Linear Regression dalam Memprediksi Kualitas Perairan Danau Ranu Grati Kabupaten Pasuruan
}

\author{
Hertiari Idajati dan Elok Wuri Safitri \\ Departemen Perencanaan Wilayah dan Kota, Fakultas Arsitektur, Desain, dan Perencanaan \\ Institut Teknologi Sepuluh Nopember (ITS) \\ e-mail: hertiari.idajati@urplan.its.ac.id
}

\begin{abstract}
Abstrak - Danau Ranu Grati sebagai tempat penampung air dan menopang berbagai kegiatan pemanfaatan di dalamnya seperti budidaya perikanan, penangkapan ikan dan pariwisata, merupakan potensi sumber daya air alami yang ada di Kabupaten Pasuruan. Kegiatan budidaya perikanan keramba yang semakin marak menyebabkan terjadinya penurunan kualitas air di danau tersebut sekaligus menimbulkan kerugian di sektor pariwisata, sektor ekonomi maupun sektor ekologis. Tujuan penelitian ini adalah untuk memprediksi nilai kualitas perairan Danau Ranu Grati di Kabupaten Pasuruan melalui metode statistik spasial untuk melihat kesesuaiannya dengan pemanfaatan kegiatan eksisting. Hasil yang didapat adalah dengan metode Spatial Linear Regression, kualitas perairan danau Ranu Grati masih mendukung kegiatan pemanfaatan Danau Ranu Grati dengan faktor suhu, pH dan Dissolved Oxygen (DO) yang diketahui memiliki pengaruh terhadap model atau rumus fungsi prediksi nilai kualitas perairan. Hasil lain yang didapat adalah Metode Spatial Linear Regression tidak dapat digunakan untuk karakteristik perairan danau yang berupa perairan tertutup dengan arus permukaan dan gelombang air yang statis.
\end{abstract}

Kata Kunci- Euclidean Distance, Kualitas Perairan, Prediksi, Spatial Linear Regression

\section{PENDAHULUAN}

$\mathrm{K}$ ABUPATEN Pasuruan merupakan salah satu kabupaten di Provinsi Jawa Timur yang memiliki cekungan pada kerak bumi yang tergenang air dengan kedalaman tertentu berupa danau alami. Menurut Satari (2000) mendefinisikan danau sebagai badan air alami yang tergenang sepanjang tahun dengan tingkat kualitas air serta produktivitas biologi yang beragam antar danau satu dengan yang lain. Adapun danau di Kabupaten Pasuruan yaitu Ranu Klakah dan Ranu Grati. Selain sebagai destinasi wisata, kedua danau tersebut memiliki beragam kegiatan pemanfaatan danau yang berhubungan erat dengan kondisi sosial dan budaya masyarakat sekitarnya.

Danau Ranu Grati, yang terletak di bagian Timur Kabupaten Pasuruan, menjadi pusat interaksi berbagai aktivitas masyarakat lokal dan sebagai sumber penghidupan yang vital bagi masyakat sekitar pada tahun 1970an. Kondisi air saat itu yang jernih dan melimpah mengakibatkan banyak aktifitas yang dilakukan di danau ini. Masyarakat sekitar telah memanfaatkan sumber daya airnya untuk sumber air bersih, pengairan lahan pertanian, kegiatan sosial-budaya, pemancingan, budidaya ikan air tawar, latihan dayung komunitas lokal hingga digunakan sebagai lokasi latihan kemiliteran. Fasilitas yang ada saat itu hanya berupa bangunan pendopo sebagai akses masuk utama dan bangunan pintu air sebagai sarana irigrasi. Sehingga pada masa itu, Danau Grati menjadi sumber penghidupan masyarakat sehari-hari. Kegiatan Larung Sesaji dilakukan setiap tahun pada Bulan Sura sebagai adat masyarakat lokal untuk menunjukkan rasa syukur kepada Tuhan Yang Maha Kuasa. Hal tersebut memperlihatkan tingginya ketergantungan terhadap air danau, maupun besarnya pengaruh danau bagi masyarakat sekitar.

Danau Rabu Grati berkembang tidak hanya sebagai sumber air bagi masyarakat sekitar tetapi juga dimanfaatkan sebagai destinasi wisata. Upaya promosi telah dilakukan oleh pemerintah Kabupaten Pasuruan pada tahun 1995 dengan melakukan pemugaran sejumlah fasilitas pendukung pariwisata seperti gapura bertuliskan "Wisata Danau Ranu Grati”, loket tiket dan tempat parkir. Agenda keolahragaan tingkat provinsi juga dilakukan yaitu dengan digelarya Olahraga Air se-JawaBali pada Tahun 2000.

Pemanfaatan Danau Ranu Grati sebagai kawasan budidaya ikan air tawar telah menempati $1,77 \%$ dari luas wilayah perairan danau. Keramba jaring apung telah banyak memakan tempat melebihi dari daya tampungnya. Menurut Machbub 2010, daya tampung sejenis danau dan waduk, khususnya untuk perizinan usaha budidaya perikanan KJA didasarkan pada alokasi $1 \%$ dari luas perairannya. Hal ini menunjukkan pemanfaatan untuk budidaya ikan air tawar tersebut telah melebihi daya tampung yang diizinkan.

Berbagai dampak telah dirasakan oleh masyarakat sekitar, akibat pengelolaannya tidak memperhatikan daya tampung dan daya dukung lingkungan di danau tersebut. Tidak ada instrumen pengelolaan yang berkelanjutan untuk mengelola, mengendalikan, melindungi maupun mengawasi kegiatan pemanfaatan Danau Ranu Grati. Kondisi perairan Danau Ranu Grati mengalami penurunan kualitasnya. Danau Ranu Grati tidak lagi digunakan masyarakat untuk keperluan sehari-hari seperti mandi, cuci dan masak karena kondisi air yang keruh dan menimbulkan gangguan kesehatan. Selain itu kerusakan lingkungan sekitar danau juga terjadi. 
Kondisi perairan Ranu Grati tersebut berpotensi tinggi memicu terjadinya eutrofikasi. Eutrofikasi merupakan fenomena blooming alga dan tumbuhan air mikro yang menyebabkan berkurangnya kadar oksigen terlarut (DO) dalam danau (Machbub, 2010). Menurut Agustiyani (2004) eutrofikasi juga semakin tinggi apabila adanya konsentrasi nitrogen dan fosfor dalam jumlah signifikan masuk ke perairan danau. Meskipun secara alami danau memiliki daya tampung dalam meminimalisir pencemaran secara alami (self purification), lambat laun daya tersebut akan menurun sehingga pencemaran yang terjadi dapat berbalik mempengaruhi secara negatif kegiatan pemanfaatan danau.

Fenomena di atas menjadi objek amatan vital berbagai penelitian. Salah satunya yang pernah dilakukan oleh pihak akademisi yaitu perhitungan okupansi keramba jaring apung pada tahun 2010 yang mana telah melebihi ambang batas luasan yang diizinkan. Kemudian pada tahun 2014-2015 dilakukan pengujian laboratorium kualitas fisika dan kimia perairan melalui pengambilan sampel air di sejumlah titik dan kedalaman tertentu, pengamatan serta pengukuran pertumbuhan ikan endemik "Lempuk" dan ikan hasil budidaya keramba jaring apung. Dari penelitian di atas berhasil mengumpulkan fenomena dan fakta penurunan kualitas perairan danau, penyebab penurunan kualitas, adanya kegiatan budidaya perikanan yang tidak terkendali dan dihasilkannya arahan-arahan yang bersifat instruktif dalam membatasi jumlah keramba sesuai daya dukung perairan Danau Ranu Grati.

Namun arahan yang dihasilkan dari penelitian tersebut dirasa kurang implementatif karena tidak memiliki kekuatan hukum sebagai regulasi serta belum adanya rekomendasi program-program pengendalian yang terintegrasi terhadap pemangku kepentingan, dalam hal ini instansi terkait yang bertanggungjawab atas berbagai kegiatan pemanfaatan Danau Ranu Grati. Penelitian di atas juga belum mencapai pembahasan terkait konflik kegiatan pariwisata danau, budidaya perikanan, penangkapan ikan dan kegiatan lainnya yang ada di lapangan. Terlebih pengukuran kualitas perairan yang dilakukan pada lima titik di tahun 2014 dan 2015, kurang dapat mencerminkan karakteristik perairan di luar titik pengambilan sampel. Sehingga perlu dilakukannya pengendalian kegiatan pemanfaatan berbasis zona yang kemudian dapat diakui kekuatan regulasinya secara hukum melalui proses legalisasi kepala daerah.

Sebelum melakukan perumusan zona, diperlukan identifikasi karakteristik perairan danau melalui penilaian kualitas perairan secara fisika dan kimiawi yang tervisualisasikan di seluruh wilayah perairannya. Visualisasi kualitas perairan yang dimaksud yaitu dilakukan dengan metode prediksi nilai kualitas perairan secara spasial. Salah satu metode prediksinya yaitu Spatial Linear Regression sebagai pengembangan atas metode regresi linier klasik terhadap lokus keruangan. Spatial Linear Regression menghasilkan rumus fungsi yang mampu memetakan tingkat kualitas perairan hasil prediksi.

\section{METODE PENELITIAN}

\section{A. Pendekatan dan Jenis Penelitian}

Penelitian ini diawali dengan melakukan studi literatur tentang faktor fisika dan kimia kualitas perairan, sumbersumber pencemaran, parameter kesesuaian kualitas perairan, kegiatan pemanfaatan danau, pengelolaan wisata danau dan pembudidayaan ikan keramba jaring apung (KJA).

\section{B. Metode Pengumpulan Data dan Analisis}

Proses pengambilan data dilakukan melalui pengumpulan data sekunder dan pengumpulan data primer. Pengumpulan data primer meliputi pengambilan data melalui pengisian kuisoner, wawancara dan observasi kondisi lapangan di wilayah penelitian. Responden yang dipilih untuk penelitian ini digolongkan ke dalam dua pembagian stakeholder pemerintah dan masyarakat. Stakeholder pemerintah yaitu Dinas Kelautan dan Perikanan Kabupaten Pasuruan serta Dinas Kebudayaan dan Pariwisata. Kemudian stakeholder masyarakat di antaranya Kelompok Pembudidaya KJA Mina Tirta Jaya, Mina Makmur dan Mina Sari.

Pengumpulan data primer ini bersifat sebagai pendukung fakta empiris sesuai kondisi eksisting di lapangan, menjelaskan fenomena-fenomena kualitatif serta inventarisasi dampak yang dirasakan masing-masing stakeholder. Sedangkan untuk pengumpulan data sekunder meliputi pengambilan data instansional, penelitian terdahulu dan dokumen kajian. Data instansional maupun dari penelitian dan kajian terdahulu berperan sangat penting karena berupa data hasil pengujian laboratorium masing-masing faktor kualitas perairan yang menjadi penentu variabel independen pada rumus fungsi yang dihasilkan.

Tabel 1.

Kebutuhan Data Sekunder dan Sumber Data

\begin{tabular}{|c|c|c|c|}
\hline Data & "Sumber & $\begin{array}{c}\text { Teknik } \\
\text { Pengumpulan } \\
\text { Data } \\
\end{array}$ & Instansi \\
\hline $\begin{array}{l}\text { Sampling Faktor } \\
\text { Fisika Kualitas } \\
\text { Perairan }\end{array}$ & $\begin{array}{l}\text { Kajian } \\
\text { Rehabilitasi }\end{array}$ & Survey Sekunder & $\begin{array}{l}\text { Dinas Kelautan } \\
\text { Dan Perikanan } \\
\text { Kabupaten } \\
\text { Pasuruan }\end{array}$ \\
\hline $\begin{array}{l}\text { Sampling Faktor } \\
\text { Kimia Kualitas } \\
\text { Perairan }\end{array}$ & $\begin{array}{l}\text { Penelitian } \\
\text { Akademis }\end{array}$ & Survey Sekunder & $\begin{array}{l}\text { Dinas Kelautan } \\
\text { Dan Perikanan } \\
\text { Kabupaten } \\
\text { Pasuruan }\end{array}$ \\
\hline
\end{tabular}

Adapun metodeanalisa yang dilakukan dimulai dengan mengidentifikasi faktor fisika dan kimia kualitas perairan danau. Tahap kedua yaitu memprediksi kualitas perairan melalui metode Spatial Linear Regression. Tahap ketiga mengidentifikasi validitas prediksi kualitas perairan. Tahap terakhir dilakukan perumusan kualitas perairan menggunakan teknik reclassify dan teknik overlay.

\section{HASIL DAN PEMBAHASAN}

\section{A. Identifikasi faktor fisika-kimia kualitas perairan Danau} Ranu Grati

Hasil identifikasi faktor fisika kualitas perairan Danau Ranu Grati diperoleh dari studi literatur faktor-faktor yang 
mempengaruhi kualitas perairan danau, klasifikasi tingkat kualitas perairan dan pengumpulan data sekunder yang bersumber dari hasil Kajian Rehabilitasi dan Konservasi Kawasan Danau Ranu Grati, Pasuruan tahun 2014. Faktor fisik yang diperoleh dari berbagai sumber tersebut, selanjutnya disesuaikan terhadap kondisi eksisiting lapangan sehingga diperoleh faktor fisika kualitas perairan sebagai berikut.

Tabel 2.

Faktor Fisik Kualitas Danau Ranu Grati

\begin{tabular}{|c|c|c|c|}
\hline \multirow{2}{*}{$\begin{array}{c}\text { Titik } \\
\text { Sampling } \\
\end{array}$} & \multirow[t]{2}{*}{ Faktor Fisika } & \multicolumn{2}{|c|}{ Nilai Kualitas Perairan } \\
\hline & & 2014 & 2015 \\
\hline \multirow[t]{3}{*}{$\mathrm{I}$} & Kecerahan (meter) & 0,7 & 0,7 \\
\hline & Suhu $(\mathrm{C})$ & 29 & 29,33 \\
\hline & tersuspensi/TSS & 120,67 & 128 \\
\hline \multirow[t]{3}{*}{ II } & Kecerahan (meter) & 0,8 & 0,7 \\
\hline & Suhu (C) & 31,33 & 29 \\
\hline & $\begin{array}{l}\begin{array}{l}\text { Padatan } \\
(\mathrm{mg} / \mathrm{L})\end{array} \\
\end{array}$ & 87,33 & 95,67 \\
\hline \multirow[t]{3}{*}{ III } & Kecerahan (meter) & 0,8 & 0,7 \\
\hline & Suhu $(\mathrm{C})$ & 31,67 & 28,67 \\
\hline & tersuspensi/TSS & 101,33 & 98,33 \\
\hline \multirow[t]{3}{*}{ IV } & Kecerahan (meter) & 0,7 & 0,70 \\
\hline & Suhu (C) & 30 & 29,67 \\
\hline & tersuspensi/TSS & 99,33 & 22,62 \\
\hline \multirow[t]{3}{*}{$\mathrm{V}$} & Kecerahan (meter) & 0,7 & 0,7 \\
\hline & Suhu $(\mathrm{C})$ & 29,33 & 29 \\
\hline & tersuspensi/TSS & 100 & 22,58 \\
\hline
\end{tabular}

Sebagaimana hasil identifikasi faktor fisika, pada tahap ini diperoleh nilai faktor kimia kualitas perairan Danau Ranu Grati dengan proses pengumpulan data yang sama yang selanjutnya disesuaikan terhadap kondisi eksisiting lapangan sehingga diperoleh faktor kimia kualitas perairan sebagai berikut.

Tabel 3.

Faktor Kimia Kualitas Perairan Danau Ranu Grati

\begin{tabular}{|c|c|c|c|}
\hline \multirow{2}{*}{$\begin{array}{c}\text { Titik } \\
\text { Sampling }\end{array}$} & \multirow[t]{2}{*}{ Faktor Kimia } & \multicolumn{2}{|c|}{ Nilai Kualitas Perairan } \\
\hline & & 2014 & 2015 \\
\hline \multirow[t]{5}{*}{ I } & $\mathrm{pH}$ & 7,72 & 7,52 \\
\hline & $\mathrm{DO}(\mathrm{mg} / \mathrm{L})$ & 7,49 & 9,97 \\
\hline & BOD (mg/L) & 24,73 & 12,73 \\
\hline & Amonia (mg/L) & 0,05 & 0,039 \\
\hline & Fosfat $(\mathrm{mg} / \mathrm{L})$ & 0,29 & 0,232 \\
\hline \multirow[t]{5}{*}{ II } & $\mathrm{pH}$ & 7,77 & 7,40 \\
\hline & $\mathrm{DO}(\mathrm{mg} / \mathrm{L})$ & 7,81 & 9,31 \\
\hline & $\mathrm{BOD}(\mathrm{mg} / \mathrm{L})$ & 28,43 & 9,8 \\
\hline & Amonia (mg/L) & 0,057 & 0,051 \\
\hline & Fosfat $(\mathrm{mg} / \mathrm{L})$ & 0,25 & 0,195 \\
\hline \multirow[t]{5}{*}{ III } & $\mathrm{pH}$ & 7,69 & 7,29 \\
\hline & $\mathrm{DO}(\mathrm{mg} / \mathrm{L})$ & 7,94 & 20,82 \\
\hline & BOD (mg/L) & 28,87 & 12,53 \\
\hline & Amonia (mg/L) & 0,06 & 0,023 \\
\hline & Fosfat (mg/L) & 0,3 & 0,209 \\
\hline \multirow[t]{5}{*}{ IV } & $\mathrm{pH}$ & 7,64 & 7,15 \\
\hline & $\mathrm{DO}(\mathrm{mg} / \mathrm{L})$ & 6,86 & 10,21 \\
\hline & BOD (mg/L) & 17,8 & 13,33 \\
\hline & Amonia (mg/L) & 0,05 & 0,024 \\
\hline & Fosfat (mg/L) & 0,36 & 0,192 \\
\hline $\mathrm{V}$ & $\mathrm{pH}$ & 7,69 & 7,43 \\
\hline
\end{tabular}

\begin{tabular}{lr|r} 
DO $(\mathrm{mg} / \mathrm{L})$ & 5,10 & 11,57 \\
\hline BOD $(\mathrm{mg} / \mathrm{L})$ & 23,2 & 14,9 \\
\hline Amonia $(\mathrm{mg} / \mathrm{L})$ & 0,029 & 0,03 \\
\hline Fosfat $(\mathrm{mg} / \mathrm{L})$ & 0,306 & 0,187 \\
\hline
\end{tabular}

\section{B. Memprediksi kualitas perairan Danau Ranu Grati}

Tahap prediksi kualitas perairan Danau Ranu Grati dilakukan menggunakan analisis spatial linear regression. Teknik analisis tersebut merupakan pengembangan dari teknis regresi linier klasik dengan sisi spasial yang membedakan. Sisi spasial tersebut memiliki maksud bahwa keberadaan suatu lokasi yang satu mempengaruhi posisi suatu objek di sekitarnya. Hubungan antara objek dan keberadaan suatu tempat tersebut mendefinisikan besar pengaruhnya. Besar pengaruh ini pada teknik spatial linear regression dimanfaatkan untuk memprediksi nilai-nilai yang tersebar merata di wilayah penelitian dari nilai yang telah diambil pada titik pengambilan sampel atau stasiun pengambilan.

Latar belakang penggunaan teknik ini yaitu jika dalam suatu observasi yang mengandung informasi keruangan, lokasi atau spasial, maka analisis data tidak mungkin akan akurat jika hanya menggunakan analisis regresi sederhana (Anselin, 1988). Akibatnya bila informasi spasial diabaikan pada data yang memiliki informasi ruang atau spasial, maka terjadi koefisien regresi akan bias atau tidak konsisten, $\mathrm{R} 2$ berlebihan dan kesimpulan yang ditarik tidak representatif karena model tidak akurat.

Teknik spatial linear regression diawali dengan melalukan perhitungan regresi linier berganda pada variabel kedekatan terhadap sumber-sumber pencemar yang ada di wilayah penelitian sebagai variabel independen atau variabel yang berdiri sendiri. Sumber-sumber pencemar menurut Pujiastuti (2013) meliputi kedekatan terhadap permukiman, lahan pertanian, keramba jaring apung dan tempat wisata. Hasil studi literatur terkait sumber pencemar tersebut menjelaskan bahwa keberadaan sumber pencemar di sekitar wilayah perairan akan cenderung memberikan dampak terhadap kualitas perairannya.

Teknik perhitungan kedekatan titik sampel terhadap sumber pencemar menggunakan euclidean distance pada software ArcGIS. Euclidean distance memvisualisasikan pengaruh kedekatan sumber pencemar dalam satuan jarak di wilayah penelitian menjadi data berformat raster. Hasil euclidean distance kemudian diproses extract multi value to point untuk merubah data raster menjadi sebaran titik-titik dengan nilai tertentu. Selanjutnya data hasil extract dari euclidean distance tersebut diproyeksikan pada masing-masing faktor kualitas perairan sebagai variabel dependennya melalui regresi linear berganda pada software Wolfram Mathematica. Proses analisis regresi berganda menghasilkan rumus fungsi atau persamaan regresi linier berganda sebagaimana pada tabel 4. Rumus fungsi tersebut mewakili persebaran nilai prediksi kualitas perairan di wilayah Danau Ranu Grati.

Tabel 4.

Rumus Fungsi Regresi Linier Berganda tiap Faktor

\begin{tabular}{cccccc}
\hline \hline $\begin{array}{c}\text { Jenis } \\
\text { Faktor }\end{array}$ & Faktor & \multicolumn{4}{c}{ Rumus Fungsi } \\
$(\mathrm{Y}=\mathrm{a}+\mathrm{bx} 1+\mathrm{cx} 2+\mathrm{dx} 3+\mathrm{ex} 4)$ & \\
\hline Fisika & Kecerahan & $\mathrm{Y}=0.632591$ & - & ("wisata_ED3.tif" & $*$ \\
& & $0.000469689)$ & + & ("pertanian_ED.tif" & $*$ \\
& & $0.000634235)$ & + & ("perkim_ED.tif" & $*$ \\
& & $0.000107636)$ & - & ("kja_ED3.tif" & $*$ \\
\hline
\end{tabular}




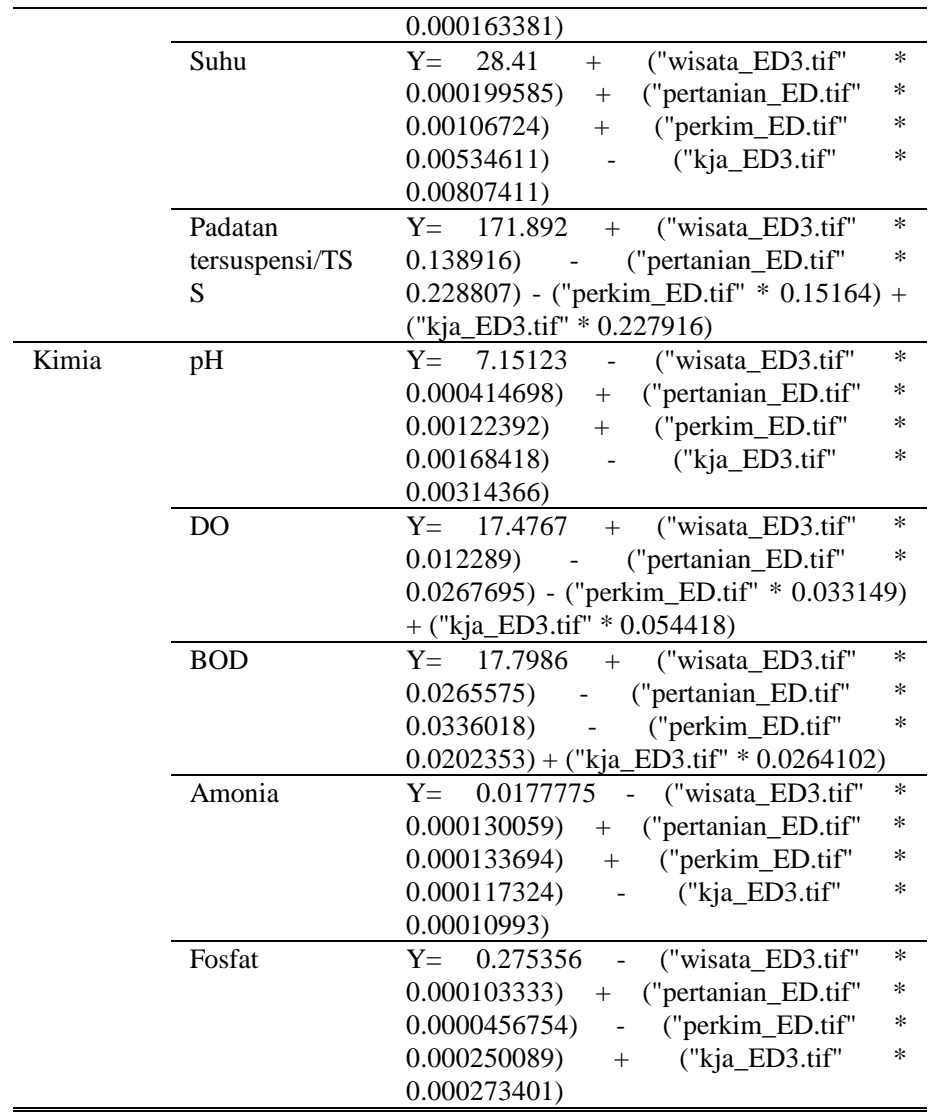

\section{Validitas prediksi kualitas perairan Danau Ranu Grati}

Validitas regresi linier berganda diketahui dengan cara melihat nilai R-Squared pada hasil output software Wolfram Mathematica. Validitas menandakan bahwa masing-masing faktor memiliki pengaruh signifikan terhadap nilai prediksi. Kondisi persebaran nilai prediksi yang dapat diterima adalah rumus fungsi yang memiliki nilai R-Squared terbesar yaitu yang mendekati $100 \%$. Hasil R-Squared tersebut terlihat pada tabel 5 berikut ini.

Tabel 5.

Hasil Perhitungan R-Squared

\begin{tabular}{|c|c|c|c|}
\hline Jenis Faktor & Faktor & $\begin{array}{l}\text { Hasil R- } \\
\text { Squared }\end{array}$ & Keterangan \\
\hline \multirow[t]{3}{*}{ Fisika } & Kecerahan & $\begin{array}{l}\text { Infinite } \\
\text { expression, } \\
\text { R2 } \approx 1\end{array}$ & $\begin{array}{l}\text { Tidak } \\
\text { terdefinisi besar } \\
\text { pengaruh }\end{array}$ \\
\hline & Suhu & $\begin{array}{r}0,870004 \\
\approx 87 \%\end{array}$ & Berpengaruh \\
\hline & $\begin{array}{l}\text { Padatan } \\
\text { tersuspensi/TSS }\end{array}$ & $\begin{array}{l}\text { Infinite } \\
\text { expression, } \\
\text { R2 } \approx 1\end{array}$ & $\begin{array}{l}\text { Tidak } \\
\text { terdefinisi besar } \\
\text { pengaruh }\end{array}$ \\
\hline \multirow[t]{5}{*}{ Kimia } & $\mathrm{pH}$ & $\begin{array}{l}0,299701 \\
29,9 \%\end{array}$ & $\begin{array}{l}\text { Berpengaruh } \\
\text { rendah }\end{array}$ \\
\hline & $\mathrm{DO}$ & $\begin{array}{l}0,543675 \\
54,3 \%\end{array}$ & $\begin{array}{l}\text { Berpengaruh } \\
\text { sedang }\end{array}$ \\
\hline & BOD & $\begin{array}{l}\text { Infinite } \\
\text { expression, } \\
\mathrm{R} 2 \approx 1\end{array}$ & $\begin{array}{l}\text { Tidak } \\
\text { terdefinisi besar } \\
\text { pengaruh }\end{array}$ \\
\hline & Amonia & $\begin{array}{l}\text { Infinite } \\
\text { expression, } \\
\mathrm{R} 2 \approx 1\end{array}$ & $\begin{array}{l}\text { Tidak } \\
\text { terdefinisi besar } \\
\text { pengaruh }\end{array}$ \\
\hline & Fosfat & $\begin{array}{l}\text { Infinite } \\
\text { expression, } \\
\mathrm{R} 2 \approx 1 \\
\end{array}$ & $\begin{array}{l}\text { Tidak } \\
\text { terdefinisi besar } \\
\text { pengaruh } \\
\end{array}$ \\
\hline
\end{tabular}

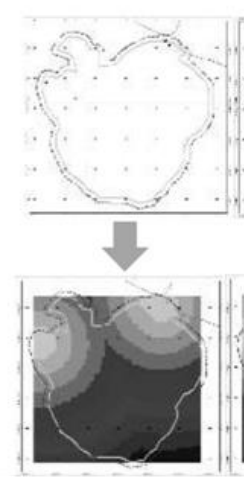

(a)

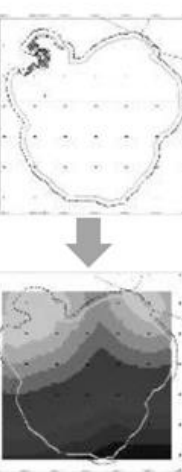

(b)

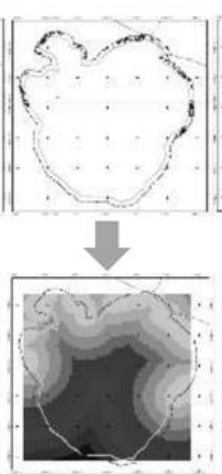

(c)

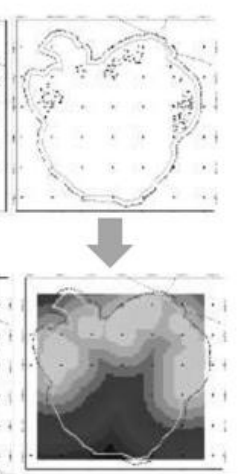

(d)

Gambar 1. Visualisasi Euclidean Distance terhadap Sumber-Sumber Pencemar: (a) Kegiatan wisata; (b) Lahan Pertanian; (c) Permukiman; dan (d) Budidaya Keramba

Terlihat pada gambar 1 bahwa dihasilkannya jenis peta raster hasil euclidean distance. Semakin dekat sumber-sumber pencemar dengan wilayah perairan, semakin besar pula pengaruhnya yang terlihat dari wilayah perairan yang berwarna kuning. Adapun pengaruh terendah ditunjukkan dengan warna biru tua. Adapun tahapan spatial linear regression secara garis besar digambarkan pada alur berikut ini.

Gambar 2. Garis Besar Alur Analisis Spatial Linear Regression pada

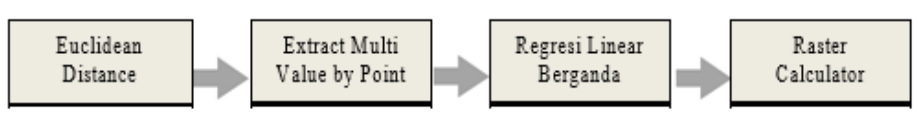

mekanisme prediksi GIS

Berdasarkan hasil pengamatan terhadap nilai R-Squared, diperoleh bahwa hanya satu faktor yang memiliki pengaruh signifikan terhadap nilai prediksi kualitas perairan yaitu faktor suhu sebesar 0,87 atau $87 \%$. Selanjutnya terdapat faktor $\mathrm{pH}$ dan Dissolved Oxygen (DO) yang berpengaruh rendah dan sedang. Adapun sebanyak lima faktor lainnya, nilai R-Squared tidak terdefinisikan besar pengaruhnya.

\section{Faktor-faktor yang memiliki pengaruh signifikan terhadap nilai prediksi kualitas perairan Danau Ranu Grati}

Berdasarkan proses spatial linear regression, hanya 3 faktor yang memiliki pengaruh signifikan terhadap nilai prediksi kualitas perairan yaitu faktor suhu, $\mathrm{pH}$ dan Dissolved Oxygen (DO). Spatial linear regression diartikan tidak sesuai terhadap model atau rumus fungsi dalam memprediksi nilai kualitas perairan pada lima faktor: kecerahan, padatan tersuspensi, BOD, amonia dan fosfat. Spatial linear regression dirasa kurang tepat sebagai metode yang memodelkan prediksi nilai kualitas perairan tertutup sejenis danau dengan dengan arus permukaan dan gelombang air yang statis. Dari segi karakteristik data masukan (input) jumlah variasi data rendah dan titik sampel yang terlalu sedikit dibandingkan luasan wilayah perencanaan mencapai 198 hektar menjadi penyebab lain berkurangnya ke-valid-an rumus fungsi yang dihasilkan.

Selanjutnya, menurut hasil validitas rumus fungsi prediksi kualitas perairan, faktor suhu, $\mathrm{pH}$ dan Dissolved Oxygen (DO) diketahui memiliki pengaruh terhadap model atau rumus 
fungsi prediksi nilai kualitas perairan. Kemudian tahap analisis berikutnya yaitu merumuskan kualitas perairan danau melalui pemetaan nilai-nilai prediksi sesuai rumus fungsi untuk ketiga faktor tersebut. Adapun lima faktor lainnya telah tereduksi karena tidak dapat mendefinisikan persebaran nilai prediksi. Apabila fungsi kelima faktor dipetakan, maka diperkirakan hasil prediksi tidak menggambarkan kondisi eksisiting perairan di wilayah pengamatan.

Rumus fungsi ketiga faktor kualitas perairan terpilih digunakan sebagai input pemetaan nilai prediksi kualitas perairan di Danau Ranu Grati menggunakan tool pada software ArcGIS berupa raster calculator. Sehingga diperoleh hasil raster nilai prediksi kualitas perairan yang kemudian dilakukan reclassify untuk mengelompokkan persebaran nilai prediksi berdasarkan parameter karakteristik kualitas perairan masingmasing faktor pada tabel 6 dari parameter ambang batas kriteria mutu air kelas II Perda Provinsi Jawa Timur No.2 Tahun 2008 dan beberapa literatur terkait lainnya. Parameter karakteristik kualitas perairan disusun berdasarkan kesesuaiannya terhadap kegiatan pemanfaatan danau berupa kegiatan budidaya ikan dan kegiatan pariwisata. Tabel 6.

Parameter Faktor Fisika dan Kimia

\begin{tabular}{llll}
\hline \hline \multicolumn{1}{c}{ Jenis Faktor } & \multicolumn{1}{c}{ Faktor } & \multicolumn{1}{c}{ Parameter } & \multicolumn{1}{c}{ Satuan } \\
\hline Fisika & Suhu & Tidak Sesuai & Deviasi 3 C \\
\cline { 3 - 4 } & & Sesuai & $29-31 \mathrm{C}$ \\
\hline \multirow{2}{*}{ Kimia } & $\mathrm{pH}$ & Tidak Sesuai & $<6,5 \mathrm{dan}>8,1$ \\
\cline { 2 - 4 } & & Sesuai & $6,5-8,1$ \\
\cline { 2 - 4 } & DO & Tidak Sesuai & $0-4 \mathrm{mg} / \mathrm{liter}$ \\
\cline { 3 - 4 } & Amonia & Sesuai & $4-10 \mathrm{mg} / \mathrm{liter}$ \\
\cline { 3 - 4 } & & Tidak Sesuai & $>10 \mathrm{mg} / \mathrm{liter}$ \\
\hline \hline
\end{tabular}

\section{a. Faktor Suhu}

Pada prediksi faktor suhu $\left({ }^{\circ} \mathrm{C}\right)$ dari tujuh titik sampel yaitu $(29,33),(29),(28,67),(29,67),(29),(29,79)$ dan $(30,23)$ diperoleh peta raster suhu yang memiliki distribusi nilai suhu terendah sebesar $22,6214{ }^{\circ} \mathrm{C}$ dan nilai tertinggi sebesar $30,8062{ }^{\circ} \mathrm{C}$. Setelah dilakukan reclassify berdasarkan parameter ambang batas kriteria mutu air kelas II Perda Provinsi Jawa Timur No.2 Tahun 2008 dalam Mulyanto (2014) yaitu deviasi $3^{\circ} \mathrm{C}$ dari suhu perairan rata-ratanya. Sehingga diperoleh dua klasifikasi tingkat suhu "sesuai" yang bernilai $26^{\circ} \mathrm{C}<\mathrm{n}<32^{\circ} \mathrm{C}, \mathrm{n} \mid \mathrm{n}=$ nilai prediksi suhu dan "tidak sesuai" yang bernilai $\mathrm{n}<26^{\circ} \mathrm{C}$.

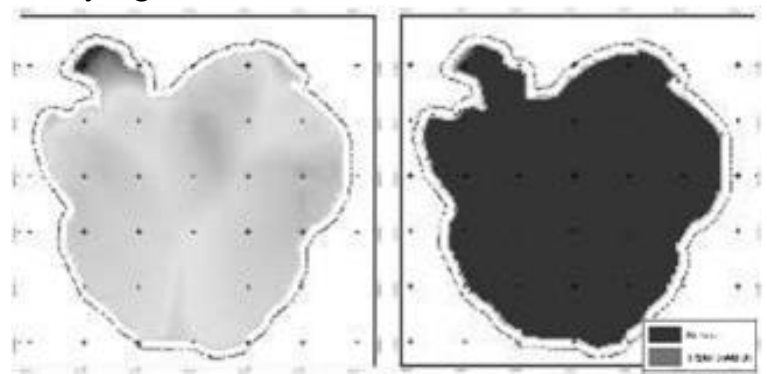

Gambar 3. Hasil Prediksi Spatial Linear Regression Faktor Suhu di Perairan Danau Ranu Grati

\section{b. Faktor $\mathrm{pH}$}

Pada prediksi faktor derajat keasaman $(\mathrm{pH})$ dari tujuh titik sampel yaitu $(7,52),(7,4),(7,29),(7,15),(7,43),(8,34)$ dan $(8,08)$ diperoleh peta raster derajat keasaman yang memiliki distribusi nilai suhu terendah sebesar 5,83438 dan nilai tertinggi sebesar 8,06147. Setelah dilakukan reclassify berdasarkan parameter derajat keasamaan optimal bagi ikan menurut NTAC dalam Mulyanto (2014) berada pada rentang pH 6,5-8,5, maka diperoleh dua klasifikasi tingkat pH "sesuai" yang bernilai $6,5<\mathrm{n}<8,5, \mathrm{n} \mid \mathrm{n}=$ nilai prediksi $\mathrm{pH}$ dan klasifikasi "tidak sesuai" yang bernilai $\mathrm{n}<6,5$ dan $\mathrm{n}>8,5$. Kesesuaian $\mathrm{pH}$ tersebut terhadap kegiatan budidaya ikan di perairan Danau Ranu Grati.
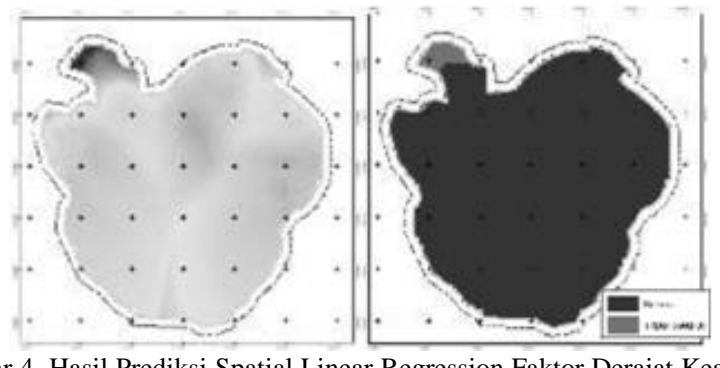

Gambar 4. Hasil Prediksi Spatial Linear Regression Faktor Derajat Keasaman di Perairan Danau Ranu Grati

\section{c. Faktor DO}

Pada prediksi faktor Dissolved Oxygen (DO) dari tujuh titik sampel yaitu $(9,97),(9,31),(20,82),(10,21),(7,43),(4,33)$ dan $(0,13)$ diperoleh peta raster DO yang memiliki distribusi nilai suhu terendah sebesar 0,13425 dan nilai tertinggi sebesar 42,5208. Setelah dilakukan reclassify berdasarkan parameter DO yang dibutuhkan untuk pertumbuhan dan kehidupan ikan menurut Effendi (2003) diperoleh tiga klasifikasi tingkat DO "sangat sesuai" yang bernilai $>10 \mathrm{mg} /$ liter, klasifikasi "sesuai" yang bernilai 4-10 mg/liter dan klasifikasi "tidak sesuai" yang bernilai < $4 \mathrm{mg} / \mathrm{liter}$. Kesesuaian DO tersebut terhadap kegiatan budidaya ikan di perairan Danau Ranu Grati.
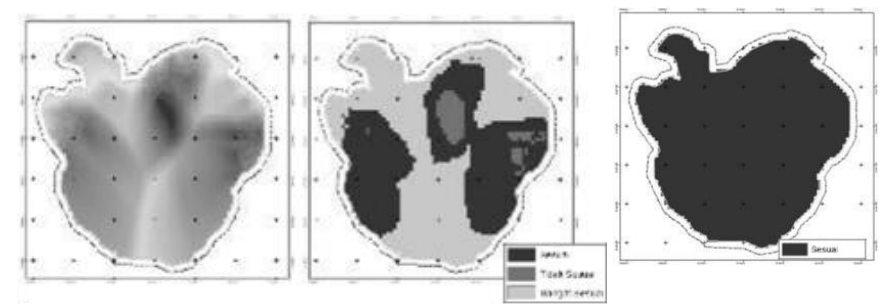

Gambar 5. Hasil Prediksi Spatial Linear Regression Faktor Dissolved Oxygen di Perairan Danau Ranu Grati

\section{E. Overlay Hasil Prediksi Faktor Kualitas Perairan}

Berdasarkan hasil prediksi nilai kualitas perairan faktor suhu, pH dan DO pada analisis spatial linear regression, maka tahap selanjutnya yaitu melakukan analisis overlay berdasarkan kesesuaian perairan. Tahap ini dimaksudkan untuk mengakumulasikan hasil prediksi nilai kualitas perairan dari tiga faktor berpengaruh sehingga dapat menggambarkan karakteristik perairan Danau Ranu Grati secara keseluruhan. Gambar 6. Hasil Overlay Prediksi Nilai Kualitas Perairan Danau Ranu Grati

Pada gambar 6 terlihat bahwa hasil overlay menunjukkan karakteristik wilayah perairan danau Ranu Grati yang 
homogen dengan klasifikasi "sesuai" terhadap kegiatan pemanfaatan danau berupa budidaya ikan dan kegiatan wisata. Hal tersebut memperlihatkan bahwa karakteristik eksisting kualitas perairan berdasarkan sampling data tahun 2015 masih mendukung kegiatan pemanfaatan Danau Ranu Grati. Sehingga menurut Peraturan Menteri Kelautan dan Perikanan No. 30 Tahun 2010 tentang Rencana Pengelolaan dan Zona Kawasan Konservasi Perairan, upaya pengendalian kegiatan di wilayah penelitian masih tergolong pada kegiatan-kegiatan perlindungan pada zona perikanan budidaya dan zona pemanfaatan (untuk wisata) di antaranya:

a. Kegiatan perlindungan habitat dan populasi ikan yang meliputi:

- Perlindunganproses-proses ekologis yang menunjang kelangsungan hidup dari suatu jenis atau sumber daya ikan dan ekosistemnya

- Pengamanan, pencegahan dan/atau pembatasankegiatan-kegiatan yangdapatmengakibatkan perubahan keutuhan potensi kawasan dan perubahan fungsi kawasan

- Pengelolaan jenis sumber daya ikan beserta habitatnya untuk dapat menghasilkan keseimbangan antara populasi dan habitatnya

- Alur migrasi biota perairan

- Pemulihan

b. Kegiatan penangkapan ikan dengan menggunakan alat penangkapan ikan yang sifatnya statis dan/atau pasif serta cara memperoleh ikan dengan memperhatikan daya dukung habitat dan/atau tidak mengganggu keberlanjutan sumber daya ikan

c. Kegiatan budidaya yang mempertimbangkan jenis ikan yang dibudidayakan, jenispakan, teknologi, jumlah unit usaha budidaya, daya dukung dan kondisi lingkungan sumber daya ikan

d. Kegiatan pariwisata dan rekreasi meliputi pariwisata minat khusus, perahu pariwisata, pariwisata pancing serta pembuatan foto, video, dan film

e. Kegiatan penelitian dan pengembangan meliputi:

- Penelitian dasar untuk kepentingan perikanan berkelanjutan dan konservasi

- Penelitian terapan untuk kepentingan perikanan berkelanjutan dan konservasi

- Pengembangan untuk kepentingan konservasi

f. Kegiatan pendidikan untuk memberikan wawasan dan motivasi yang meliputi aspek:

- Biologi

- Ekologi

- Sosial ekonomi dan budaya

- Tata kelola dan pengelolaan

\section{KESIMPULAN DAN REKOMENDASI}

Berdasarkan tahapan dan hasil analisis dapat ditarik kesimpulan sebagai berikut:

1.) Reduksi faktor yang terjadi menunjukkan bahwa untuk tujuan penelitian yang mempersyaratkan penilaian karakteristik perairan yang ditinjau dari hasil keseluruhan nilai kualitas perairan sesuai literatur, maka metode spatial linear regression tidak berhasil memprediksi seluruh faktor. Hal ini disebabkan karakteristik perairan danau yang berupa perairan tertutup dengan arus permukaan dan gelombang air yang statis. Selain itu karakteristik data masukan memiliki jumlah variasi data rendah dan titik sampel yang terlalu sedikit dibandingkan luasan wilayah perencanaan mencapai 198 hektar.

2.) Dari delapan faktor kualitas perairan yang diamati, diperoleh hanya tiga faktor yang memiliki pengaruh signifikan terhadap model atau rumus fungsi prediksi nilai kualitas perairan, yaitu faktor fisika berupa suhu dan faktor kimia berupa derajat keasaman $(\mathrm{pH})$ dan dissolved oxygen (DO).

3.) Proses reclassify dari pemetaan regresi linier menghasilkan klasifikasi "tidak sesuai", "sesuai" dan "sangat sesuai" pada tiga faktor kualitas perairan berpengaruh

4.) Proses overlay menghasilkan satu klasifikasi "sesuai" terhadap kegiatan kegiatan pemanfaatan danau. Hal ini memperlihatkan bahwa karakteristik eksisting kualitas perairan masih mendukung kegiatan pemanfaatan Danau Ranu Grati.

Berdasarkan hasil kesimpulan di atas, maka dapat diperoleh rekomendasi sebagai berikut:

- Diperlukan eksplorasi uji-uji data kuantitatif pendukung yang sesuai dengan cara kerja bahasa pemrograman software Mathematica Wolfram.

- Melengkapi proses validasi hasil prediksi nilai kualitas menggunakan observasi lapangan dengan media lembar pengamatan.

\section{DAFTAR PUSTAKA}

[1] Peraturan Menteri Kelautan dan Perikanan No. 30 Tahun 2010 tentang Rencana Pengelolaan dan Zona Kawasan Konservasi Perairan

[2] Peraturan Menteri Negara Lingkungan Hidup No. 28 Tahun 2009 tentang Daya Tampung Beban Pencemaran Air Danau dan/atau Waduk.

[3] Adjie, S. 2008. Zonasi, karakteristik fisika-kimia air dan jenis-jenis ikan yang tertangkap di Sungai Musi, Sumatera Selatan. Jurnal Ilmu-Ilmu Perairan dan Perikanan Indonesia, Vol.15 No.1, 41-48 hal.

[4] Agustiyani, D. 2004. Proses Terjadinya Penyuburan (Eutrofikasi) dan Dampaknya di Perairan. Manajemen Bioregional Jabodetabek Profil \& Strategi Pengelolaan Sungai \& Aliran Air. Bogor: LIPI. 97-107 hal

[5] Anselin L. 1988. Spatial Econometrics, Methods and Models. Dordrecht: Academic Publishers.

[6] Effendi, H. 2003. Telaah Kualitas Air bagi Pengelolaan Sumber Daya dan. Lingkungan Perairan. Yogjakarta: Kanisius, 258 hal.

[7] Kementerian Pekerjaan Umum dan Perumahan Rakyat. 2013. Buku Informasi Statistik Pekerjaan Umum (BIS PU) Tahun 2013. Jakarta: Sekretariat Jendral PUSDATIN.

[8] Machbub, Badruddin. 2010. Model Perhitungan Daya Tampung Beban Pencemaran Air Danau dan Waduk. Jurnal Sumber Daya Air, Vol.6 No.2, November 2010: 103-104.

[9] Mulyanto. 2014. Daya Dukung Ranu Grati Untuk Budidaya Ikan Nila Dalam Keramba Jaring Apung Pada Kajian Rehabilitasi dan Konservasi Ranu Grati

[10] Kabupaten Pasuruan 2014. Kabupaten Pasuruan: Dinas Kelautan dan Perikanan.

[11] Pujiastuti, P., Ismail, B., \& Pranoto, P. 2013. Kualitas Dan Beban Pencemaran Perairan Waduk Gajah Mungkur. Jurnal Ekosains Universitas Sebelas Maret Surakarta, Vol. 5 No. 1. 
[12] Purhadi, P., \& Khaulasari, H. 2014. Pemodelan Mixed

Geographically Weighted Regression Multivariate Pada Pencemaran Kualitas Air Chemical Oxygen Demand (COD) Dan Biological Oxygen Demand (BOD). Jurnal Sains dan Seni ITS, Vol.3 No.2.

[13] Rahayu, J., Utami, T. W., \& Wasono, R. 2016. Pemodelan Kualitas Air di Kawasan Pegunungan Kendeng dengan Pendekatan Ordinary

[14] Kriging dan Geographic Information System (GIS). Jurnal Statistika Universitas Muhammadiyah Semarang, Vol. 4 No.2.

[15] Satari, G. 2000. Pengelolaan dan Pemanfaatan Danau dan Waduk. Dalam Proseding Semiloka Nasional. Bandung: Universitas Padjadjaran.

[16] Soesilo, R. S. 1992. Pengelolaan dan Pemanfaatan Sumberdaya Perikanan Perairan Umum Sumatera Selatan. Proceeding TKI, PPU. Jakarta: Puslitbangkan. 62-67, 231 hal.

[17] Ward Michael D., dan Gleditsch Kristian S. 2007. An Introduction to Spatial Regression Model in the Social Sciences. Washington, USA dan Colchester, United Kingdom 